\title{
Reflexões sobre a TeOria da DesobediênCIA Civil eM RaWls: Roteiro Para UMA OBJEÇÃO E UMA POSSÍVEL JUSTIFICAÇ̃̃O DO APELO À CONSCIÊNCIA
}

\author{
[ Reflections on Rawl's Theory of Civil Disobedience: ScRipt for an obJection and a \\ POSSIBLE JUSTIFICATION FOR THE APPEAL TO CONSCIENCE ]
}

Gehad Marcon Bark* Universidade Federal do Paraná, Brasil

RESUMO: A proposta do artigo é refletir sobre uma possível justificação da desobediência civil em situações políticas nas quais não temos ao nosso dispor princípios políticos que traduzam uma concepção arrazoada de justiça à qual possamos apelar para justificar o descumprimento da lei. Embora ofereça uma definição de desobediência civil bastante útil, John Rawls se ocupa de sua justificação somente quando há uma concepção de justiça que rege o espaço público. $\mathrm{O}$ autor explicitamente se afasta do problema inicialmente apresentado afirmando que, em contextos políticos autoritários, a desobediência civil é válida na medida em que quaisquer meios se justificam para transformar um governo injusto. É preciso inspecionar com mais cuidado a concepção defendida por Rawls. Há uma questão legítima que, a um só tempo, impõe a recusa da solução oferecida pelo autor e recoloca a tarefa de pensar sobre a justificação da desobediência civil. Autores como Henry-David Thoreau e Hannah Arendt, bem como um exemplo literário extraído do romance D. Quixote, em contrapartida, propiciam reflexões que auxiliam na tarefa de encontrar um caminho para a análise da questão que considere pressupostos diversos daqueles que operam na justificação de Rawls. Nessa perspectiva, parece possível justificar ao menos uma tese mais fraca, a dizer, a que afirma que a consciência individual não pode ser excluída, de antemão, como um possível critério para justificarmos o uso da desobediência civil.

Palavras-Chave: consciência; desobediência civil; justiça; lei; princípios políticos
ABSTRACT: This paper aims at reflecting on a possible justification for the civil disobedience in political contexts in which we do not have at our disposal political principles that express a reasonable conception of justice to which we may appeal in order to justify the disobedience of the law. Although he offers a quite useful definition to civil disobedience, John Rawls considers its justification only when such conception of justice regulates de public arena. The writer explicitly detour the initial problem by saying that, in authoritarian political contexts, civil disobedience is valid since any means are justifiable to transform an unfair government. It is necessary to consider Rawls' conception. There is a legitimate question that not only demands Rawls' solution denial but relocate the task on thinking civil disobedience justification. Writers like Henry-David Thoreau and Hannah Arendt as well as an example from the novel Don Quixote, on the other hand, offer ideas that assist us on the task of finding a way to analyze the question that considers distinct assumptions as the ones operating in Rawls' justification. In this perspective, it seems possible to justify at least a weaker thesis, namely, the one that says that individual conscience cannot be beforehand precluded as one possible criterion to justify the use of civil disobedience.

KEYWORDS: conscience; civil disobedience; justice; law; political principles.

* Programa de Pós-Graduação em Filosofia da Universidade Federal do Paraná-UFPR. m@ilto: gehad_marcon_bark@hotmail.com. 


\section{INTRODUÇ̃̃o}

a obra Uma Teoria da Justiça, John Rawls define a desobediência civil como "um
ato político público, não-violento e consciente contra a lei, realizado com o fim de provocar uma mudança nas leis ou nas políticas de governo"1. Parece razoável assumir que, em circunstâncias políticas favoráveis à ampla liberdade de pensamento e manifestação política, seria legítimo recorrer à desobediência civil para questionar normas que violam frontalmente princípios fundamentais. Rawls se ocupa da justificação desses atos unicamente na última hipótese, isto é, quando há uma autoridade democrática constituída e um padrão razoável de justiça, afirmando que a desobediência civil é um recurso válido na medida em que seja "orientado e justificado por princípios políticos"2.

Quero sustentar que outra questão igualmente relevante surge, todavia, quando refletimos sobre a justificação desses atos em contextos políticos que não apenas não promovem, mas cerceiam as liberdades políticas. Quando a própria concepção de justiça não é razoável, ou mesmo injusta, e a comunidade cultiva "princípios" antidemocráticos, por assim dizer, parece que temos razões legítimas ao menos para formular a seguinte questão: se não há um padrão razoável de justiça que possa orientar a conduta política dos indivíduos, não estariam os cidadãos legitimados a recorrer a uma avaliação pessoal acerca da equidade da lei para justificar que venham a desobedecê-la? É válido um apelo à consciência ${ }^{3}$ ? Essas perguntas podem ser desdobradas e tratadas, mais detalhadamente, a partir de duas questões que pretendo considerar nas páginas seguintes: i) é necessário compreender, em primeiro lugar, em que medida a tarefa de reconsiderar a justificação da desobediência pode ser colocada quando refletimos sobre um sistema político no qual não vige um padrão de justiça; ii) em um segundo momento, admitindo que a primeira questão é legítima, é crucial pensarmos como a desobediência civil pode ser justificada nos casos em que não há princípios políticos que traduzam uma concepção de justiça.

A primeira seção trata da questão apresentada em i), reconstruindo o problema a partir da reflexão de Rawls na obra Uma Teoria da Justiça. Na seção seguinte, por sua vez, indico, ainda que de maneira tateante, caminhos para tratarmos da questão sugerida em ii) recuperando elementos do pensamento de Henry-David Thoreau e Hannah Arendt, bem como um instigante exemplo, a partir da literatura, que aparece na clássica obra de Cervantes, $O$ engenhoso cavaleiro D. Quixote de La Mancha. Em ambos os casos são ensaiadas interessantes reflexões que podem lançar luzes na pretendida análise do problema a partir de um registro distinto daquele que é considerado por Rawls.

\section{COLOCANDO EM QUESTÃo A JUSTIFICAÇ̃̃o DA DESOBEDIÊNCIA CIVIL: RAWLS E O APELO A PRINCíPIOS POLÍTICOS}

Proponho que iniciemos essa reflexão a partir do seguinte questionamento: a desobediência civil, no contexto de uma estrutura política que suprime direitos políticos essenciais e elege "princípios" fundamentais que não traduzem uma concepção de justiça, seria um recurso válido à disposição dos indivíduos? Parece claro e intuitivo que, com ainda maior razão, ao cidadão é dado questionar determinadas normas e políticas no seio de um governo autoritário. Se podemos assumir essa posição como razoável, então outra questão se coloca: como justificar esses atos de desobediência civil? Para refletir sobre essa última pergunta, contudo, devemos antes compreender em que sentido há, efetivamente, uma questão em torno do problema da justificação dos atos de desobediência civil em situações políticas em que não há princípios democráticos que traduzam uma certa concepção de justiça e que possam reger a vida política.

John Rawls elabora uma teoria da desobediência civil que pode auxiliar na delimitação do problema que temos de considerar. Na obra Uma Teoria da Justiça, Rawls define a desobediência civil como "um ato político público, não-violento e consciente contra a lei, realizado com o fim de provocar uma mudança nas leis ou nas políticas de governo" ${ }^{\text {. Essa definição }}{ }^{5}$ é introduzida depois de uma prévia discussão sobre as razões pelas quais temos o dever de obedecer mesmo àquelas leis injustas, à luz dos princípios básicos pactuados, em um contexto de "quase justiça", ou seja, "um estado no qual a estrutura básica da sociedade é aproximadamente justa, levandose apropriadamente em conta aquilo que é razoável esperar nas circunstâncias" ". Para resumir a questão ao essencial, a discussão é principiada com a indicação de razões que teríamos para crer 
que, em um contexto de quase justiça, não é toda e qualquer iniquidade que legitimaria os cidadãos a recorrerem, de imediato, à desobediência civil.

Pela proposta de Rawls, princípios políticos (deliberados em uma posição original e consensualmente adotados) sedimentam a base sobre a qual o funcionamento das instituições e o comportamento dos indivíduos uns em relação aos outros serão avaliados em uma esfera de atuação e participação coletiva. As diretrizes que pautam esse convívio são fixadas em um momento prévio (e suposto) de escolha dos princípios básicos da estrutura política e fundam uma concepção de justiça. O princípio da equidade, segundo Rawls, seria um dos princípios escolhidos para ordenar a vida em sociedade e, no que é essencial para a presente discussão, desdobra-se em dois aspectos, a dizer: estabelece a maneira pela qual as obrigações são adquiridas, ou seja, mediante atos caracterizados por sua voluntariedade, com os benefícios deles decorrentes, e; condiciona a observância da obrigação à justiça da estrutura básica, estabelecendo que "aceitar instituições explicitamente injustas [...] não gera obrigações"”. Nesse contexto, concorrem, igualmente, os chamados "deveres naturais, positivos ou negativos". $\mathrm{O}$ dever de justiça é um dos deveres naturais básicos, exigindo tanto "apoio e obediência às instituições justas", quanto a cooperação para a instituição de "arranjos justos" ". No modelo proposto em que os princípios básicos da estrutura são respeitados, as obrigações e os deveres de justiça coordenam a vida dos indivíduos em sociedade.

Para o autor, "a verdadeira questão está em saber quais circunstâncias e até que ponto somos obrigados a obedecer a arranjos institucionais injustos" 10 . Em um contexto político tal como o sugerido, ao tratarmos da desobediência civil, surge um conflito de deveres, pois "alguns princípios recomendam a obediência, ao passo que outros nos conduzem à direção oposta"11. Como regra geral, o dever natural de apoio às instituições justas recomenda que, mesmo leis e políticas injustas, dentro de um contexto de quase justiça, sejam obedecidas, "contanto que elas [as leis] não ultrapassem certos limites da injustiça"12. Dado que o contexto é de quase justiça, isto é, que nem toda política instituída pode satisfazer plenamente a totalidade dos ideais almejados pela comunidade, os cidadãos devem arcar com um "dever natural de civilidade"13 que impõe que algumas falhas sejam suportadas para manter a estrutura geral de confiança mútua, partilhando-se de uma concepção de justiça e promovendo o respeito às instituições vigentes sob a crença de que os demais partícipes também se conduzem e devem se conduzir dessa mesma maneira perante a comunidade. A questão é, assim, decidir sob que circunstâncias o dever de obediência cede lugar à possibilidade de dissentir.

No contexto de quase justiça, a desobediência civil é um recurso válido na medida em que, mesmo no interior de uma sociedade bem ordenada, podem ocorrer graves transgressões dos princípios de justiça. Nessas situações, para Rawls, não se poderia exigir dos cidadãos que sempre e invariavelmente obedecessem a leis iníquas, ou se conformassem com determinadas políticas que não estão conformes aos padrões pactuados, sob o pretexto de se preservar incólume uma estrutura política apenas porque o seu arranjo, à exceção das violações apontadas, é razoavelmente justo na maioria dos casos. Rawls não é explícito ao indicar quais seriam essas graves transgressões, mas, a partir da leitura de diversas passagens do texto, tudo leva a crer que seriam aquelas violações diretas e explícitas dos princípios de justiça que embasam a constituição e o funcionamento regular das instituições.

$\mathrm{Na}$ análise de Rawls, ao praticar a desobediência civil nessas situações, sob o pressuposto de que há um padrão publicamente reconhecido, o agente recorre ao "senso de justiça da maioria da comunidade e declara que em sua opinião ponderada os princípios da cooperação entre homens livres e iguais não estão sendo respeitados"14. Essa espécie de violação possui outra característica fundamental, qual seja, a de ser uma "desobediência à lei dentro dos limites da fidelidade à lei" 15 , isto é, um ato político, por ser "orientado e justificado por princípios políticos"16 que embasam a concepção de justiça da sociedade ${ }^{17}$.

Esta última característica nos coloca diante do problema que a justificação dos atos de desobediência em circunstâncias políticas adversas suscita. Para Rawls, mais uma vez, em uma ordem política que é razoavelmente justa e que dispõe de padrões políticos de justiça, a desobediência civil é passível de justificação apenas com base nesses princípios fundamentais da ordem política, de tal sorte que, "ao justificar a desobediência civil, ninguém apela aos princípios da moralidade pessoal"18. É especialmente essa limitação imposta por Rawls que nos leva a questionar a justificação da desobediência civil em contextos políticos nos quais não vige um padrão de justiça: como justificar a desobediência civil em um contexto no qual os padrões de justiça não promovem a pluralidade política? É lícito apelar, por exemplo, para princípios da 
moralidade pessoal? Em caso não tenhamos nem mesmo esse recurso à nossa disposição, a que outro meio podemos nos apegar?

Para deixar a questão mais clara: Rawls reconhece que as normas e políticas podem ser injustas ou bem por se afastarem dos padrões políticos de justiça vigentes, ou bem quando "essa própria concepção pode não ser razoável, sendo até, em muitos casos, claramente injusta"19. Mas Rawls restringe sua análise ao primeiro caso e confessa que não vai se ocupar de formas de governo outras que não aquelas que suponham uma autoridade democrática, argumentando que casos extremos não colocam um problema efetivo, pois a oposição pela desobediência civil seria válida na medida em que quaisquer meios se justificam para "transformar ou mesmo depor um sistema injusto e corrupto"20.

É claro que todos aqueles que partilham de uma compreensão razoável sobre as finalidades de uma comunidade política estão dispostos a assumir que a desobediência civil seria um recurso válido com ainda maior razão contra arbitrariedades cometidas por governos autoritários instituídos à revelia do processo democrático. Mas isso não nos exime de considerar razões mais profundas para justificar a desobediência civil mesmo nesses contextos.

O problema é que o argumento de Rawls está fundado em um juízo condicional que afirma que, se todos os meios se justificam para depor um sistema injusto, então a desobediencia civil também se justifica. Esse argumento não é satisfatório por pelo menos dois motivos. Em primeiro lugar, é trivial e pouco esclarecedor afirmar que um meio específico é válido se todos os meios se justificam em função de uma dada finalidade. Essa abordagem nos desloca do problema da justificação da desobediência civil para o problema da adequação de meios a fins. Se o fim almejado é tomado como legítimo, e todo e qualquer meio é válido em função da promoção do fim, a desobediência civil passa a ser, muito claramente, apenas mais um instrumento a ser empregado (e, a bem da verdade, não o meio mais eficaz dentre os demais), pouco importando uma reflexão efetiva sobre as condições mediante as quais o seu uso pode ser justificado em determinados contextos.

Em segundo lugar, há uma questão ainda mais fundamental: é pouco crível que possamos tomar como verdadeiro que todos os meios se justificam em função de uma dada finalidade, ainda que a finalidade seja a deposição de um sistema político injusto. Na verdade, a justificação dessa afirmação, mesmo para o caso particular da deposição de um governo autoritário, pode ser muito mais problemática do que Rawls parece sugerir. Basta imaginar que o único meio cabível para alcançar a finalidade almejada acarrete mais danos à população do que aqueles que as circunstâncias vigentes já promovem. Suponhamos, a título de reflexão, uma situação contrafactual extremamente crítica em que a deposição de um governo autoritário dependa, necessariamente, da eliminação de metade da população de um país, incluindo-se pessoas inocentes e engajadas na luta contra a tirania no cômputo daqueles que devem ser eliminados: nessa hipótese, ainda que a finalidade almejada seja legítima, poderíamos convictamente afirmar que o meio empregado é válido? Poderíamos, à luz desse exemplo, afirmar que todo e qualquer meio é justificado para depor um governo autoritário? Creio que poucos estariam dispostos a responder que mesmo a eliminação em massa de pessoas inocentes seria justificável se o que se almeja obter é a deposição do governo autoritário.

Disso podemos concluir, pelo menos, que é razoável pensar em razões para crermos que a desobediência civil pode ser justificada, ainda que não possamos endossar, como parece ser o caso, a tese que afirma que todos e quaisquer meios são justificados mesmo em contextos políticos adversos. Ora, que nem todos os meios disponíveis sejam legítimos e justificados para contestar alguma prática autoritária ou um governo (eliminação em massa de pessoas inocentes, por exemplo, é uma hipótese a ser recusada), não implica que um meio em particular, como a desobediência civil, não o seja. Formalmente, podemos dizer que, quando pensamos na proposição 'se todos os meios se justificam para depor um sistema injusto, então a desobediencia civil também se justifica', podemos negar o antecedente, sem que tenhamos de negar o consequente (do contrário, estaríamos comprometidos com a conhecida falácia da negação do antecedente). Isso parece suficiente para recolocar a tarefa de pensar as condições para a justificação da desobediência civil.

As reflexões de Rawls nos auxiliaram na delimitação da questão, mas a solução apresentada pelo autor não satisfaz inteiramente os nossos propósitos. É interessante observar que, ao propor que a desobediência civil seja justificada por princípios políticos, Rawls está operando em um registro que é comum no pensamento ocidental. Na falta de um termo mais preciso, vou provisoriamente chamá-lo de modelo hierárquico. $\mathrm{O}$ aspecto essencial desse modelo 
de justificação é, como visto, o apelo a algum princípio mais elementar, seja qual for a sua origem, que justifique que uma norma positiva seja descumprida.

Para ilustrar brevemente a discussão com outros exemplos, podemos retomar, da antiguidade clássica, os acontecimentos em torno dos quais gravita a terceira peça que compõe a Triologia Tebana, denominada Antígona. Antígona, filha de Edipo, irmã de Ismene e de Polinices, é a personagem principal dessa terceira peça. Polinices e Etéocles, em confronto, matam um ao outro, em confronto, por conta da disputa pelo trono de Tebas. Antígona decide conceder a Polinices as honras fúnebres, contrariando o édito publicado por Creonte que, mediante a cominação de pena de morte aos infratores, proibiu expressamente que Polinices fosse sepultado, por considerá-lo um traídor. $\mathrm{O}$ aspecto fundamental que quero retomar é que Antígona decide desobedecer a norma publicamente por considerar que o decreto, enquanto objeto de uma deliberação do governante cidade, não necessariamente corresponde a um mandamento de justiça, que só poderia ser veiculado por meio de "normas divinas, não escritas, inevitáveis"21. Antígona, posteriormente endossada em sua resolução pelas professias do vidente Tirésias, afirma que as determinações de Creonte não possuíam obrigatoriedade suficiente para impor o dever de desobedecer leis divinas que impunham que o corpo de Polinices fosse sepultado.

Entre os modernos, de igual maneira, para citar brevemente apenas um exemplo, o mesmo modelo surge na obra Leviatã. Hobbes afirma, de maneira suficientemente clara, que a obediência aos princípios seculares é devida na medida requerida pela justiça e afirma, ainda, que na hipótese de "os chefes não possuírem um mandato justo, mas usurpado, ou quando seus preceitos forem injustos, os súditos não têm nenhuma obrigação de obedecer" 22 . É claro que não podemos equiparar, sem mais, o pensamento dos três autores aqui considerados. No entanto, há, muito claramente, um ponto em comum justamente nesse aspecto hierárquico da justificação que motiva a desobediência da lei. É justamente esse elemento requerido para a justificação da desobediência civil que torna concepções desse tipo insuficientes para a nossa análise.

\section{REPENSANDO A JUSTIFICAÇÃO DA DESOBEDIÊNCIA CIVIL: UM POSSÍVEL APELO À CONSCIÊNCIA}

Um rápido recuo talvez possa nos encaminhar na tentativa de sugerir uma abordagem que mobilize elementos diversos dos propostos por Rawls e outros autores. Henry-David Thoreau oferece uma contribuição relevante para a presente discussão, no conhecido ensaio intitulado " $A$ desobediência civil", datado de 1848. Nesse texto, Thoreau argumenta que a razão pela qual mesmo governos democráticos tomam decisões não é que "seja mais provável que tal maioria esteja certa, nem a de que isso pareça o mais justo à minoria, e sim a de que a maioria é fisicamente mais forte" 23 . Sob esse pressuposto, toda a reflexão que Thoreau desenvolve a respeito da justificação da desobediência civil está fundada em uma indagação quanto à possibilidade da existência de um governo em que o apelo à consciência pessoal seja um expediente fundamental para sopesar a justiça ou injustiça das normas e políticas institucionalizadas, formalmente, segundo a vontade da maioria.

Thoreau, que esteve preso na cidade de Concord, Massachusetts, por se negar a pagar impostos, escreveu explicitamente contra duas políticas do governo norte-americano inegavelmente condenáveis: a escravidão dos negros e a guerra contra o México pelo domínio de territórios atualmente localizados no sul dos Estados Unidos. O autor reconhece os limites da desobediência civil e compara o funcionamento do Estado ao de uma máquina, afirmando que aquele primeiro, assim como a última, possui atritos, mas certamente é provido de "aspectos bons que compensem os maus" 24 . O direito de resistir surge, segundo a metáfora empregada, a partir do momento em que "a fricção chega a dominar sua máquina, e a opressão e o roubo se organizam"25. Para Thoreau, uma vez que a adoção de um modelo democrático não necessariamente implica a adoção das práticas políticas mais justas, mas sim daquelas que são majoritariamente referendadas pelo povo (independentemente, muitas vezes, do seu conteúdo), é válida a resistência pacífica fundada em alguma espécie de reflexão pessoal sobre a equidade da norma.

Quando refletimos sobre condutas movidas por esse fundamento em um contexto democrático no qual as instituições funcionam regularmente, a objeção que pode ser levantada é óbvia: aparentemente não há limites claros para a ação quando o indivíduo recorre apenas à sua 
própria consciência como parâmetro para agir. Eis um dos motivos pelos quais, possivelmente, o pensamento político contemporâneo, de maneira geral, condiciona a justificação da desobediência civil ao crivo dos princípios políticos. Além disso, Thoreau parece partilhar da problemática crença segundo a qual não há verdadeiramente um dever de buscar a modificação de determinada política, a menos que o contestador perceba estar sendo utilizado como instrumento da injustiça que, pessoalmente, condena. Ele afirma, explicitamente, que se a injustiça "for de natureza tal que exija de vós que sejais agente de injustiça para com outrem, então vos digo: infringe a lei" 26 .

A despeito desses aspectos controversos e da tendência contemporânea de se tratar a justificação de atos de desobediência civil como condicionada à observância de princípios políticos previamente pactuados, quero propor, justamente, que, em sua essência, a concepção de Thoreau acerca da centralidade das reflexões pessoais sobre a equidade da norma nos oferece um critério válido para considerar o problema da legitimidade em contextos políticos nos quais os padrões públicos de justiça promovem não a liberdade e condições para um desenvolvimento pessoal e político pleno, mas a supressão de direitos e garantias fundamentais. Prosseguindo com essas observações, aliadas ao argumento central de Thoreau, as reflexões de Hannah Arendt sobre a moralidade em sua relação com a política, parecem indicar um caminho para suprir a insuficiência desse aspecto em que a concepção de Rawls deixa de oferecer uma resposta satisfatória para a questão que inspira as reflexões desse artigo.

Hannah Arendt afirma que "a moralidade diz respeito ao indivíduo na sua singularidade", não dependendo "nem dos hábitos e costumes que partilho com aqueles ao meu redor nem de uma ordem de origem divina ou humana" 27 . Nessa ordem de ideias, a moralidade está fundada em uma deliberação individual, particular, a respeito daquilo que é o correto a se fazer. O indivíduo avalia as condutas com os quais pessoalmente pode ou não se comprometer, tendo como critério de decisão um juízo sobre a possibilidade de poder conviver consigo mesmo. Independentemente dos pormenores dessa concepção, para Arendt, essa "moralidade socrática só é politicamente relevante em tempos de crise" 28 , ou, ainda, "é a única moralidade operativa em situações limitrofes, isto é, em tempos de crise e emergência" ${ }^{29}$. E, mais importante, há inúmeras situações em que "padrões políticos e morais e conduta podem entrar em conflito" 30 . Essa moralidade socrática parece operar, pela concepção da filósofa, como um princípio prático válido justamente em determinados contextos nos quais os padrões e princípios políticos objeto de algum pacto social não apenas não promovem, mas atentam contra a plena realização do homem enquanto ser capaz de ação e discurso.

A partir dessas reflexões, parece que podemos avançar apenas se, uma vez enunciada a tese em questão, pudermos justificá-la. Dependeríamos exatamente de justificar que, seja qual for a norma, sempre há algum espaço para um questionamento individual que pode eventualmente conduzir o indivíduo a contestar alguma lei. Um motivo para apostar nessa tese parece consistir em que é razoável admitir, como faz Hannah Arendt, que, ao menos idealmente, as leis positivas devem "erigir fronteiras" e "estabelecer canais de comunicação entre os homens" 31 , preservando a liberdade de cada um e de todos para agir em meio à pluralidade constituinte das comunidades políticas. Calcados fundamentalmente em pactos, os sistemas legais podem ser definidos por serem projetados para estabilizar as relações humanas, preservando a condição que esses seres possuem para agir politicamente. É por intermédio de suas ações que, invariavelmente, os indivíduos estabelecem relações entre si, agregando suas existências únicas à pluralidade inerente ao campo político. A exigência que esse modo característico de reunião impõe é que, enquanto espécie de manifestação por vezes imprevisível, a ação deve ser limitada por marcos que possibilitem a convivência possível entre seres humanos. Se um sistema cumpre essa função que lhe atribuímos, "abolir as cercas da lei entre os homens (...) significa tirar dos homens os seus direitos e destruir a liberdade como realidade política viva" 32 .

Se partilhamos dessa compreensão, e lembrando que nosso intuito é considerar situações políticas extremas, o apelo para essa espécie de moralidade à qual Arendt faz alusão não pode ser excluído na medida em que, seja qual for a comunidade em que estejamos inseridos, quando as instituições não mais funcionam regularmente, devemos dispor de um expediente último por intermédio do qual possamos avaliar se a norma cumpre com a tarefa de regular as relações humanas de modo a permitir essa convivência plural entre indivíduos. Essa é uma concepção que claramente atribui às leis a tarefa de regular as relações humanas de tal forma a permitir que distintas visões de mundo convivam de forma tão harmoniosa quanto possível.

Alguém poderia objetar, entretanto, que justamente por pressupormos uma tal concepção, já estamos argumentando a partir de um padrão que deve nortear a elaboração das leis da 
comunidade política. Há, nesse mesmo sentido, um padrão razoável a ser seguido do ponto de vista político quando se trata de pensarmos a possibilidade de recorrermos à desobediência civil. A justificação da desobediência estaria inscrita, assim, no mesmo registro que já é considerado de forma satisfatória por Rawls, o que não nos auxilia muito a avançar quando consideramos contextos políticos adversos (se pretendemos recusar que quaisquer meios são válidos para modificar um governo autoritário).

Um segundo motivo para encararmos esse último argumento com ressalvas é que não fíca absolutamente claro que Hannah Arendt compartilhe dessa visão, especialmente a partir das reflexões contidas em ensaio publicado no início da década de 70, intitulado Desobediência Civil. Embora as passagens anteriormente citadas sugiram que Arendt poderia admitir algum espaço para esse apelo à consciência como justificativa da desobediência civil, nesse último texto a autora trata do fenômeno político em questão afirmando explicitamente que "argumentos levantados em prol da consciência individual ou de atos individuais (...) são inadequados quando aplicados à desobediência civil" 33 . O cerne da objeção que Arendt claramente acolhe é, justamente, a ausência de limites claros em relação aos motivos que podem levar o cidadão a desobedecer uma determinada norma. Numa tentativa de conciliar os dois textos, é possível sustentar que, ao tratar da distinção entre os campos da política e da moral, Arendt considera a validade de atos de desobediência civil fundados em uma reflexão individual justamente em situações limítrofes hipotéticas, ao passo que, no texto da década de 70, o recorte da análise é, concretamente, o sistema jurídico e político dos Estados Unidos da época (no qual, presumidamente, vigorava um padrão razoável justiça e havia um espaço público para o debate de ideias).

Embora os textos mencionados possam ser compatibilizados, persiste, todavia, a objeção primeiramente considerada: ao recorrermos ao pensamento de Arendt, atribuindo à lei a tarefa estabilizar as relações humanas por meio de canais de comunicação, recorremos a um padrão de justiça, ainda que mínimo, a partir do qual as normas positivas serão avaliadas. Mais do que isso, para oferecer uma resposta adequada, teríamos de lidar com um problema aparentemente mais profundo: a objeção, recorrente, segundo a qual não há limites que possam orientar a conduta pessoal de cada indivíduo se o parâmetro para agir é, unicamente, a consciência. À luz dessas questões, talvez tenhamos de recuar um passo, partindo de uma concepção de lei depurada, em termos políticos, para que possamos justificar ao menos a adoção de outro ponto de partida que oriente nossas reflexões. Podemos começar sugerindo o seguinte questionamento: supondo que a lei seja um instrumento que, em termos muito gerais, prescreve condutas e comina sanções para comportamentos contrários aos prescritos, como justificar que possamos deixar de cumpri-la em geral?

Quero propor que há uma maneira de justificar uma tese mais fraca que em certa medida acomoda os últimos problemas mencionados. Essa tese mais fraca afirma que o apelo à consciência não pode ser excluido de antemão enquanto um possível recurso do qual o indivíduo possa lançar mão ao desobedecer uma norma legal. Em relação à objeção que se apoia na ausência de limites em relação aos motivos que podem fundar o ato de desobediência, essa abordagem contorna a questão reconhecendo que o problema dos limites é efetivo e relevante, mas propõe que, para considerá-lo em toda a sua profundidade, é necessário, invariavelmente, ter em conta cada situação concreta em que possibilidade de desobedecer se coloca diante do indivíduo ou de um grupo de pessoas. Em outras palavras, é apenas por intermédio da análise circunstancial de ocorrências historicamente localizáveis que a questão dos limites poderá ser ponderada adequadamente. O ponto é que essa questão não pode servir como escusa, sem mais, para recusarmos, de forma absoluta, a via de justificação aqui proposta. E a tese mais fraca indicada parece nos colocar em uma posição favorável para discutir o problema, pois, um tanto à maneira de Thoreau e Arendt (com as qualificações anteriormente consideradas), está centrada na importância de uma reflexão arrazoada, ainda que pessoal, sobre a norma descumprida. É dizer, ainda que posteriormente venhamos a concluir que determinadas condutas não estavam legimitadas, essa espécie de justificação preserva sua relevância na medida em que pode vir a ser o único expediente disponível em situações políticas extremas (a exemplo do que sucede com a situação que Rawls se exime de considerar em sua teoria da desobediência civil).

Colho da literatura a reflexão com base na qual pretendo oferecer uma justificativa para a tese enunciada. No Livro II de Dom Quixote o leitor se depara com um relato no mínimo curioso. Depois de assumir o governo de sua Ínsula, Sancho Pança é chamado a solucionar os mais diversos embaraços trazidos ao seu conhecimento pelos seus súditos. Em uma das inusitadas 
situações, conta-se que havia uma ponte, ao cabo da qual fora construída uma forca e constituído um tribunal composto por quatro juízes aos quais incumbiria examinar se os passantes poderiam ou não seguir viagem. A norma vigente era clara: aquele que dissesse a verdade seguiria viagem, aquele que mentisse, seria enforcado. Por longo período a norma foi rigorosamente aplicada sem dificuldades. Um dia, entretanto, ao solicitar a passagem, um indivíduo "deu por jura que ia para morrer na forca" ${ }^{34}$. Eis a questão: se o homem seguisse livre, teria mentido e deveria morrer pela forca, mas se morresse pela forca, teria falado a verdade e, então, deveria passar. Depois de meditar longamente sobre o assunto, Sancho recorre aos ensinamentos de seu mestre Dom Quixote e, sabiamente, decide deixar o homem passar, argumentando que, diante da dúvida em relação à solução mais adequada a um determinado caso, deve-se apelar para a misericórdia.

O paradoxo suscita uma interessante reflexão quando o tomamos para avaliar criticamente o ponto de partida das reflexões sobre a nossa relação com as leis positivas. Nicholas Rescher, na obra Paradoxes: their Roots, Range and Resolution assevera que estamos diante de um paradoxo cuja solução repousa justamente sobre a negação de uma premissa implícita que, via de regra, admitimos como verdadeira em nossas reflexões sobre o dever de obediência às normas: a premissa segundo a qual uma norma legal sempre deve ser obedecida ${ }^{35}$. Ora, o caso levado ao conhecimento de Sancho Pança era tal, que nenhuma solução seria capaz de satisfazer a exigência da lei: se o passante seguisse viagem, a norma seria desobedecida por ser devida a morte do indivíduo que mentiu; fosse enforcado, a norma seria descumprida por ter o viajante dito a verdade, fazendo jus à passagem requerida.

A concepção fundamental que está operando no argumento em questão sustenta que, dado que aquilo que não é possível não é obrigatório (como já dizia, aliás, o princípio romano ultra posse nemo obligatur), então o paradoxo, de uma maneira um tanto curiosa, nos leva a negar a premissa segundo a qual a norma sempre deve ser obedecida, premissa que muitas vezes assumimos de maneira irrefletida. Esse pode ser um ponto de partida interessante para discussões contemporâneas sobre direito de resistência, mais particularmente sob a forma da desobediência civil. Nesse registro, podemos formalizar um argumento da seguinte maneira: i) a lei positiva deve ser sempre cumprida; ii) contudo, não ser possível cumprir a lei implica não ser devido cumprir a lei; iii) por modus tollens, é possível concluir de ii) que ser devido implica ser possível; iv) mas há casos em que não é possível agir de acordo com as prescrições das leis positivas; v) se há circunstâncias em que impossível seguir a lei, então não pode ser exigível cumpri-la sempre; vi) a conclusão exposta em v), amparadas nas premissas anteriores, contradiz a premissa em i), a ser negada.

Para concluir essa tentativa de justificação, e sem obviamente pretender fechar a questão, cumpre registrar que, via de regra, o ponto de partida das discussões sobre a relação entre os indivíduos e a norma é justamente o de que a lei deve ser obedecida. Não seria o caso de submeter esse pressuposto a uma inspeção mais cuidadosa? Talvez a partir dessa abordagem inicial, ancorada nas sugestões de Thoreau e Arendt, encaremos com mais naturalidade esse apelo à consciência como necessário para a avaliação das leis positivas. Ao negarmos a premissa segundo a qual a lei positiva deve ser sempre cumprida, pretendemos unicamente sustentar que portar-se perante a lei assumindo esse pressuposto de forma irrefletida é uma postura que, em muitos casos, pode ser altamente perniciosa, especialmente quando a comunidade não dispõe de um padrão de justiça que fomente a liberdade e a pluralidade política. É nesse sentido que o apelo à consciência não pode ser excluído de antemão enquanto um possível recurso do qual o indivíduo possa lançar mão ao desobedecer uma norma legal. Se a tese defendida é mais fraca do que aquela que se poderia exigir que fosse justificada, ela ao menos pretende contribuir para o debate colocando em tensão premissas que muitas vezes são admitidas sem uma maior reflexão nas discussões sobre a relação entre o cidadão e as leis.

\section{CONSIDERAÇÕes FINAIS}

Há duas observações finais a serem feitas. Em primeiro lugar, a argumentação construída em favor da legitimidade de propor-se uma questão sobre a justificação da desobediência tem dois propósitos: i) mostrar que a resposta de Rawls é insatisfatória (pelas razões já indicadas); ii) sugerir que há dois modelos de justificação contrapostos, sendo o modelo hierárquico insuficiente quando nos debruçamos sobre a análise da desobediência civil nas situações em que não há um padrão de justiça vigente. 
Como segundo observação, vale registrar que, se essa proposta foi razoavelmente justificada, então ao menos pensar novos pressupostos para as reflexões é algo que se segue naturalmente, ainda que não se aceite o argumento apresentado em favor da tese segundo a qual o apelo à consciência não pode ser excluído de antemão enquanto um possível recurso do qual o indivíduo possa se valer ao desobedecer uma norma legal.

\section{REFERÊNCIAS}

Referências

ARENDT, Hannah. Crises da república. Tradução de José Volkmann: 2. ed. São Paulo: Perspectiva, 2008.

ARENDT, Hannah. Origens do totalitarismo. Tradução de Roberto Raposo: São Paulo: Companhia das Letras, 1989.

ARENDT, Hannah. Responsabilidade e julgamento. Tradução de Rosaura Einchenberg: São Paulo: Companhia das Letras, 2004.

BOBBIO, Norberto; MATTEUCCI, Nicola; PASQUINO, Gianfranco. Dicionário de política. Tradução de Carmen Varrialle; Gaetano Lo Mônaco; João Ferreira; Luís Guerreiro Pinto Caçais: 5. ed. Brasília: Ed. da UNB, 2000. v.1.

CERVANTES, Miguel de. O engenhoso cavaleiro D. Quixote de La Mancha. Tradução de Sérgio Molina: São Paulo: Ed. 34, 2010.

DWORKIN, Ronald. Uma questão de princípios. Tradução de Luís Carlos Borges: 2. ed. São Paulo: Martins Fontes, 2005.

HOBBES, Thomas. Leviathan. New York: Oxford University Press, 2008.

RAWLS, John. Uma teoria da justiça. Tradução de Jussara Simões: 3. ed. São Paulo: Martins Fontes, 2008.

RESCHER, Nicholas. Paradoxes: their Roots, Range and Resolution. Chicago: Open Court Publishing Company, 2001.

SÓFOCLES. A trilogia tebana: Édipo rei, Édipo em Colono e Antígona. Tradução de Mário da Gama Kuri: 6. ed. Rio de Janeiro: Jorge Zahar Editor, 1997.

THOREAU, Henry David. A desobediência civil e outros ensaios. Tradução de José Paulo Paes: São Paulo: Cultrix, 1968.

LAFER, Celso. A reconstrução dos direitos humanos: um diálogo com o pensamento de Hannah Arendt. São Paulo: Companhia das Letras, 2009.

\section{Notas}

1 RAWLS, John. Uma teoria da justiça. Tradução de Jussara Simões: 3. ed. São Paulo: Martins Fontes, 2008, p. 453.

2 Ibid., p. 455.

3 Alguém poderia estranhar o emprego do termo "desobediência civil" e a tentativa de encontrar uma justificativa pela via do apelo à consciência, já que Rawls distingue, muito claramente, os fenômenos da desobediência civil e da objeção de consciência. Considerado o problema que pretendo abordar, eventual disputa em torno da distinção seria meramente nominal. Em ambos os casos está em questão alguma oposição a normas positivadas. Além disso, Rawls é explícito ao reconhecer que a definição apresentada em sua obra é mais restrita do que aquelas que aparecem em outros autores, tais como Henry-David Thoreau (RAWLS, 2008, p. 458). Finalmente, mesmo autores contemporâneos conferem um significado mais amplo para o termo. Ronald Dworkin, por exemplo, distingue três tipos de desobediência civil: i) baseada na integridadade; ii) baseada na justiça, e ; iii) baseada em política (DWORKIN, Ronald. Uma questão de princípios. Tradução de Luís Carlos Borges: 2. ed. São Paulo: Martins Fontes, 2005, p. 156). Acompanhando a tipologia de Dworkin, a primeira espécie, enquanto fundada em um juízo pessoal acerca da inadequação da norma, aproximase da espécie de justificação que o presente texto pretende considerar. Assim, o emprego do termo com um sentido mais amplo não coloca um p roblema maior para o argumento desenvolvido.

4 RAWLS, 2008, p. 453.

5 A razão para o apelo ao texto de Rawls é claro: a definição de desobediência civil oferecida é útil por delimitar o núcleo semântico em torno do qual a questão será desenvolvida. Podemos ilustrar a discussão com outras concepções semelhantes. No Dicionário de Política de Bobbio, Matteuci e Pasquino a desobediência civil é definida como "omissiva, coletiva, pública, pacífica, não necessariamente parcial (a ação de Gandhi foi certamente uma ação revolucionária) e não necessariamente passiva" (BOBBIO, Norberto; MATTEUCCI, Nicola; PASQUINO, Gianfranco. 
Dicionário de política. Tradução de Carmen Varrialle; Gaetano Lo Mônaco; João Ferreira; Luís Guerreiro Pinto Caçais: 5. ed. Brasília: Ed. da UNB, 2000. v.1, p. 337). Celso Lafer, propondo resgate histórico em torno dos usos do termo, sustenta serem características fundamentais da desobediência civil "o caráter predominantemente não-violento da resistência individual à opressão $e$ à injustiça", bem como "a dimensão de uma ação de grupo, que se exprime através de uma resistência coletiva" (LAFER, Celso. A reconstrução dos direitos humanos: um diálogo com o pensamento de Hannah Arendt. São Paulo: Companhia das Letras, 2009, p. 200).

6 RAWLS, 2008, p. 438.

7 Ibid., p. 428.

8 Ibid., p. 137.

9 Ibid., p. 138.

10 Ibid., p. 437.

11 RAWLS, 2008, p. 437.

12 Ibid., p. 441.

13 RAWLS, loc. cit.

14 Ibid., p. 454

15Ibid., p. 456.

16 Ibid., p. 455.

17 Nesse mesmo registro de análise, parece haver algum consenso em relação a uma outra característica do fenômeno político em questão: a desobediência civil, em um contexto no qual vige uma concepção razoável de justiça, é um expediente a ser utilizado não como regra, mas como exceção. Para Rawls, é necessário que se observe que "os meios legais para obter a reparação de nada serviram" (RAWLS, 2008, p. 464). Segundo Hannah Arendt, a desobediência civil passa a ser utilizada quando "um número significativo de cidadãos se convence de que [...] os caminhos normais para mudanças já não funcionam" (ARENDT, Hannah. Crises da república. Tradução de José Volkmann: 2. ed. São Paulo: Perspectiva, 2008, p. 68). Finalmente, conforme Dworkin, "as pessoas [...] não devem violar a lei a menos que esses meios políticos normais não ofereçam mais esperança de sucesso" (DWORKIN, 2005, p. 160).

18 RAWLS, 2008, p. 455.

19 Ibid., p. 439.

20 Ibid., p. 452.

21 SÓfOCLES. A trilogia tebana: Édipo rei, Édipo em Colono e Antígona. Tradução de Mário da Gama Kuri: 6. ed. Rio de Janeiro: Jorge Zahar Editor, 1997, p. 214.

22 HOBBES, Thomas. Leviathan. New York: Oxford University Press, 2008, 3, XLIII.

23 THOREAU, Henry David. A desobediência civil e outros ensaios. Tradução de José Paulo Paes: São Paulo: Cultrix, 1968, p. 21.

24 THOREAU, loc. cit.

25 Ibid., p. 22.

26 THOREAU, 1968, p. 28.

27 ARENDT, Hannah. Responsabilidade e julgamento. Tradução de Rosaura Einchenberg: São Paulo: Companhia das Letras, 2004, p. 162.

28 ARENDT, 2004, p. 169.

29 Ibid., p. 172.

30 Ibid., p. 221.

31 Ibid., p. 517.

32 Ibid., p. 518

33 ARENDT, 2008, p. 55-56.

34 CERVANTES, Miguel de. O engenhoso cavaleiro D. Quixote de La Mancha. Tradução de Sérgio Molina: São Paulo: Ed. 34, 2010 , p. 541.

35 RESCHER, Nicholas. Paradoxes: their Roots, Range and Resolution. Chicago: Open Court Publishing Company, 2001, p. 63. 